\title{
Nasopharyngeal Cancer pM1 TNM Finding v6 and v7
}

National Cancer Institute

\section{Source}

National Cancer Institute. Nasopharyngeal Cancer pM1 TNM Finding v6 and v7. NCI

Thesaurus. Code C64484.

Nasopharyngeal cancer with distant metastasis. (from AJCC 6th and 7th Eds.) 